\title{
Fatty acid composition of milk from multiparous Holstein cows treated with bovine somatotropin and fed $n-3$ fatty acids in early lactation ${ }^{1}$
}

\author{
M. Carriquiry, ${ }^{* 2}$ W. J. Weber, ${ }^{*}$ C. R. Dahlen, $†$ G. C. Lamb, $\ddagger^{3}$ L. H. Baumgard,$\S^{4}$ and B. A. Crooker ${ }^{* 5}$ \\ ${ }^{*}$ Department of Animal Science, University of Minnesota, St. Paul 55108-6118 \\ †Northwest Research and Outreach Center, University of Minnesota, Crookston 56716-5000 \\ $\ddagger$ North Central Research and Outreach Center, University of Minnesota, Grand Rapids 55744-3361 \\ $\S$ Department of Animal Sciences, University of Arizona, Tucson 85721-0038
}

\section{ABSTRACT}

Multiparous cows $(\mathrm{n}=59)$ were blocked by expected calving date and previous milk yield and assigned randomly to treatments to determine effects of bovine somatotropin (bST; Posilac, Monsanto Animal Agricultural Group, St. Louis, MO) and source of dietary fat on milk fatty acid composition during the first $140 \mathrm{~d}$ in milk. Diets were provided from calving and included whole, high-oil sunflower seeds (SS; $10 \%$ of dietary dry matter; n-6/n-3 ratio of 4.6) as a source of linoleic acid or a mixture of Alifet-High Energy and Alifet-Repro (AF; Alifet USA, Cincinnati, OH; 3.5 and $1.5 \%$ of dietary dry matter, respectively; n-6/n-3 ratio of 2.6 ) as a source of protected n-3 fatty acids (15.7\% 18:3, 1.3\% 20:5, and $1.3 \%$ 22:6). Treatments were derived from a $2 \times 2$ combination of supplemental fat source (SS, AF) and with 0 (SSN, AFN) or 500 (SSY, AFY) mg of bST administered every $10 \mathrm{~d}$ from 12 to $70 \mathrm{~d}$ in milk and at 14-d intervals thereafter. Milk fatty acid composition was determined in samples collected from 32 cows $(8$ complete blocks) during wk 2, 8, and 20 of lactation. Data were analyzed as repeated measures using mixed model procedures to determine the effects of diet, bST, week of lactation, and their interactions. Proportions of $18: 3$ (4.02 vs. $3.59 \pm 0.16 \%$ ), $20: 5$ (0.52 vs. $0.41 \pm$ $0.02 \%)$, and $22: 6(0.11$ vs. $0.02 \pm 0.02 \%)$ were greater and the n-6/n-3 fatty acid ratio (7.40 vs. $8.80 \pm 0.30)$

Received September 1, 2008.

Accepted June 19, 2009.

${ }^{1}$ This work was supported in part by a Doctoral Dissertation Research Grant from the Graduate School at the University of Minnesota, a Hueg-Harrison Fellowship, and a Sigma Delta Epsilon Fellowship all awarded to M. Carriquiry. Support for the study was also provided by the Agricultural Experiment Stations at the University of Arizona (project number ARST-136339-H-24-130) and University of Minnesota (project number 16-46).

${ }^{2}$ Current address: Facultad de Agronomía, Avda. Garzón 810, 12900

Montevideo, Uruguay.

${ }^{3}$ Current address: University of Florida-NFREC, 3925 Highway 71 , Marianna, FL 32446-8091.

${ }^{4}$ Current address: Department of Animal Sciences, Iowa State University, Ames, IA 50011-3150.

${ }^{5}$ Corresponding author: crook001@umn.edu was reduced in milk from cows fed AF compared with SS. Proportions of de novo-synthesized fatty acids increased and preformed fatty acids decreased as lactation progressed, but bST administration delayed this shift in origin of milk fatty acids. Transfer efficiency of 18:3, 20:5, and 22:6 from AF to milk fat averaged 36.2, 4.9, and $5.2 \%$, respectively. These efficiencies increased as lactation progressed, but were delayed by bST. Apparent mammary $\Delta^{9}$-desaturase activity and milk conjugated linoleic acid (cis-9, trans-11 conjugated linoleic acid) content increased through the first 8 wk of lactation. Based on the product-to-substrate ratio of 14:1/14:0 fatty acids in milk, there was an interaction of diet and bST because bST decreased apparent $\Delta^{9}$-desaturase activity in SSY cows but increased it in AFY cows (0.10, $0.09,0.08$, and $0.09 \pm 0.01$ for SSN, SSY, AFN, and AFY, respectively). Feeding Alifet-Repro increased n-3 fatty acids in milk and bST prolonged the partitioning of dietary fatty acids into milk fat.

Key words: bovine somatotropin, n-3 fatty acid, milk fat

\section{INTRODUCTION}

Supplemental dietary fats are included in dairy cow rations to increase energy density of the diet, to improve reproduction (Staples et al., 1998; Mattos et al., 2000) and immune function (Lessard et al., 2004), and to increase the functional food value of dairy products (Lock and Bauman, 2004). Milk fatty acid composition affects organoleptic qualities, has important roles in milk processing, and may affect human health. Although not supported (Prentice et al., 2006), some epidemiological evidence indicates that a reduced proportion of saturated fatty acids (SFA) and a decreased n-6/n-3 fatty acid ratio in human diets would help reduce the risk of cardiovascular diseases and cancer (Kang, 2005). Potential beneficial health effects of cis9, trans-11 18:2 (a conjugated linoleic acid; CLA) and trans-11 18:1 (vaccenic acid; VA) were demonstrated in cell and animal models, including reduced incidence of cancer, atherosclerosis, obesity, and diabetes and im- 
proved modulation of the immune response (Bauman et al., 2006).

Milk and milk products contribute up to $30 \%$ of the total fat intake by humans (Mansbridge and Blake, 1997). Although milk is the main source of CLA in the human diet (Bauman et al., 2006), only $4 \%$ of the fatty acids in milk are polyunsaturated (PUFA; Mansbridge and Blake, 1997). As milk production and management intensity have increased, the proportion of fresh forages in typical diets for dairy cows has decreased and the dietary n-6/n-3 fatty acid ratio has increased from 0.5 to 6 (Ponter et al., 2006). There have been recent efforts to increase n-3 PUFA in dairy cow diets and dairy products in an attempt to improve cow health and fertility and to increase the perceived healthfulness of dairy products.

Dietary unsaturated fatty acids (UFA) normally undergo extensive biohydrogenation in the rumen. Therefore, to increase absorption of UFA and subsequent incorporation into tissues and milk, UFA need to be protected from rumen microbial metabolism. Linolenic (18:3), eicosapentaenoic (20:5, EPA), and docosahexaenoic (22:6, DHA) acids in Alifet-Repro (Alifet USA, Cincinnati, $\mathrm{OH}$ ) are partially protected from biohydrogenation (Carriquiry et al., 2008). Therefore, feeding Alifet-Repro could increase postruminal availability and incorporation of these fatty acids into milk fat.

Contributions of the primary components (fat, protein, lactose, TS, and SNF) of milk generally do not differ between bST-treated and untreated cows during a full lactation (Bauman and Vernon, 1993). Nevertheless, administration of bST can reduce the proportion of short- and medium-chain fatty acids and can increase the proportion of long-chain fatty acids when cows are treated with bST in early (Lormore et al., 1990) or mid to late (Eppard et al., 1985) lactation. Similarly, proportions of SFA decrease and UFA increase when cows are treated with bST (Eppard et al., 1985; Lormore et al., 1990). The objectives of this study were to determine the effects of bST and dietary fat enriched with n-3 fatty acids on fatty acid content of milk fat during the first 140 DIM.

\section{MATERIALS AND METHODS}

\section{Animals, Experimental Design, and Treatments}

Detailed descriptions of the diets, animal management, data and sample collection and analyses, and production responses have been reported (Carriquiry et al., 2009). Briefly, multiparous cows $(\mathrm{n}=59)$ were fed the same dry cow diet beginning 3 wk before their expected calving date. Cows were blocked by expected calving date and previous milk yield (305-d matureequivalent milk yield) and assigned randomly to 1 of 4 treatments in a $2 \times 2$ factorial arrangement of bST (0 or $500 \mathrm{mg} /$ injection) and source of supplemental dietary fat. Treatment diets contained either whole, high-oil sunflower seeds (SS; $10 \%$ of dietary DM) as a source of linoleic acid $(18: 2$; dietary $\mathrm{n}-6 / \mathrm{n}-3$ ratio $=4.6)$ or a mixture of Alifet-High Energy (Alifet USA) and Alifet-Repro (AF; 3.5 and $1.5 \%$ of dietary DM, respectively) as a source of n-3 fatty acids (dietary n-6/n-3 ratio $=2.6$ ). Alifet-High Energy is a microcrystallized rumen-inert energy concentrate made from animal fat (99\%) rich in SFA (57\% stearic acid, 18:0; $25 \%$ palmitic acid, 16:0). Alifet-Repro is a microcrystallized rumeninert fat (flaxseed oil and fish oil) that is enriched with the n-3 fatty acids linolenic (18:3; 15.7\%), EPA (20:5; $1.3 \%)$, and DHA (22:6; $1.3 \%)$.

Treatment diets were fed as TMR and were formulated to meet the nutritional needs (NRC, 2001) of the cows. Diets were composed primarily of alfalfa haylage, corn silage, high-moisture shelled corn, soybean meal, and distillers dried grains with solubles $(25,25,18$, 12 , and $6 \%$ of $\mathrm{DM}$, respectively). The treatment diets contained $60 \% \mathrm{DM}, 18.5 \% \mathrm{CP}, 18.5 \% \mathrm{ADF}, 28 \% \mathrm{NDF}$, and $8.2 \%$ ether extract. Diets were designed to differ only in the type of fatty acids they contained and were formulated to contain similar amounts of $\mathrm{NE}_{\mathrm{L}}(1.68$ and $1.71 \mathrm{Mcal} / \mathrm{kg}$, respectively) at a predicted peak DMI of $29.9 \mathrm{~kg} / \mathrm{d}$ (4.7× maintenance; NRC, 2001), but $\mathrm{NE}_{\text {L-Actual DMI }}$ values throughout the study were 1.54 and $1.66 \mathrm{Mcal} / \mathrm{kg}$ for SS and AF, respectively. Dietary content of all other major components differed by less than $4 \%$ between diets (Carriquiry et al., 2009).

Treatment diets were offered from calving, and administration of bST (Posilac, Monsanto Animal Agricultural Group, St. Louis, MO) was initiated on $12 \pm$ 3 DIM and continued at 10-d intervals through $70 \pm 3$ DIM and at 14-d intervals thereafter. Treatments from the $2 \times 2$ factorial arrangement of diets $(\mathrm{SS}, \mathrm{AF})$ with $0(\mathbf{N})$ or $500 \mathrm{mg}(\mathbf{Y})$ of bST per injection were designated SSN, SSY, AFN, and AFY, and there were 15, 16,15 , and 13 cows per treatment, respectively.

Cows were milked 2 times per day and milk weights were recorded at each milking. Milk samples were collected to determine fat, protein, lactose, and SCC (605/360 Combi-Foss instrument, Foss Electric, Hillerød, Denmark) at a commercial laboratory (Stearns DHIA Laboratories, Sauk Centre, MN). Evening milk samples from a subset of cows (32 of 59 cows, 8 complete blocks) were collected during wk 2,8 , and 20 of lactation, stored at $-20^{\circ} \mathrm{C}$ without preservative, and analyzed for fatty acid composition. Amounts of feed offered and refused were recorded daily to determine feed intake. Samples of feed ingredients and diets were 
Table 1. Fatty acid composition of diets

\begin{tabular}{|c|c|c|}
\hline \multirow[b]{2}{*}{ Variable $^{1}$} & \multicolumn{2}{|c|}{ Diet $^{2}$} \\
\hline & SS & $\mathrm{AF}$ \\
\hline \multicolumn{3}{|c|}{ Fatty acid ( $\mathrm{mg} / \mathrm{g}$ of fatty acids) } \\
\hline 12:0 & 1.2 & 3.0 \\
\hline 14:0 & 3.7 & 15.7 \\
\hline $15: 0$ & 1.2 & 2.2 \\
\hline $16: 0$ & 154.3 & 198.9 \\
\hline $17: 0$ & 2.2 & 4.8 \\
\hline 18:0 & 41.3 & 146.1 \\
\hline $18: 1$ trans $-6-8$ & $\mathrm{ND}^{3}$ & 13.1 \\
\hline $18: 1$ trans -9 & ND & 9.9 \\
\hline $18: 1$ trans -10 & ND & 8.2 \\
\hline 18:1 trans -11 & ND & 7.1 \\
\hline $18: 1$ trans -12 & ND & 10.3 \\
\hline $18: 1$ cis -9 & 236.6 & 134.3 \\
\hline $18: 2$ cis- 9, cis- 12 & 382.9 & 264.7 \\
\hline $18: 3$ cis- 9, cis- 12, cis- 15 & 83.1 & 97.5 \\
\hline $20: 0$ & 4.6 & 6.0 \\
\hline $20: 3$ & 5.0 & 3.7 \\
\hline $20: 5$ (EPA) & 0.4 & 2.6 \\
\hline 22:6 (DHA) & 0.2 & 1.8 \\
\hline Unknown $^{4}$ & 82.5 & 70.2 \\
\hline Ratio $n-6 / n-3^{5}$ & 4.6 & 2.6 \\
\hline
\end{tabular}

${ }^{1}$ Fatty acid composition obtained from analyses of the mixed diet except for eicosapentaenoic acid (EPA) and docosahexaenoic acid (DHA). Contents of EPA and DHA were calculated from analyses of sunflower seeds, Alifet-High Energy (Alifet USA, Cincinnati, OH), and Alifet-Repro (Alifet USA) and their contribution to the diet.

${ }^{2}$ Diets supplemented with whole, high-oil sunflower seeds (SS) or with a mixture of Alifet-High Energy and Alifet-Repro (AF). Diets contained 8.6 and $7.7 \%$ ether extract for the SS and AF diet, respectively.

${ }^{3}$ Not detected.

${ }^{4}$ Unidentified fatty acids.

${ }^{5}$ Ratio of (18:2 cis-9, cis-12) to (18:3 cis-9, cis-12, cis-15 + EPA + DHA).

collected throughout the study for chemical and fatty acid analyses (Table 1). Animal care and experimental procedures were approved by the University of Minnesota Institutional Animal Care and Use Committee.

\section{Fatty Acid Analysis}

Lipids in the Alifet-High Energy, Alifet-Repro, and each diet were extracted and fatty acid methyl esters were prepared and quantified by gas chromatography (Carriquiry et al., 2008). Milk fat was extracted (Hara and Radin, 1978) and fatty acid methyl esters were prepared by transmethylation (Christie, 1982) with modifications (Chouinard et al., 1999). Fatty acid methyl esters were quantified by using a gas chromatograph (GC system 6890, Hewlett-Packard, Wilmington, DE) equipped with a flame-ionization detector and a CP7489 fused-silica capillary column $(100 \mathrm{~m} \times 0.25 \mathrm{~mm}$ i.d. with $0.2-\mu \mathrm{m}$ film thickness; Varian, Walnut Creek, CA). Gas chromatograph oven characteristics and gas variables were as described previously (Moore et al., 2004). Chromatogram peaks were identified and quanti- fied by using pure methyl ester standards (GLC60, NuChek Prep, Elysian, MN; Matreya Inc., Pleasant Gap, PA; anhydrous milk fat, R.T. Corporation, Laramie, WY) and the butter oil reference standard (anhydrous milk fat, R.T. Corporation) was used to determine recoveries and correction factors for individual fatty acids, as described previously (Griinari et al., 1998; Moore et al., 2004).

\section{Calculations and Statistical Analysis}

Transfer efficiencies of linolenic acid, EPA, and DHA from Alifet-Repro were calculated as the difference in milk secretion of the fatty acid (AF - SS, g/d) divided by the difference in dietary intake of the fatty acid $(\mathrm{AF}-\mathrm{SS}, \mathrm{g} / \mathrm{d})$ and are reported as percentages. All statistical analyses were conducted with SAS System programs (SAS Institute Inc., Cary, NC). Data were analyzed as a randomized block design by repeated measures using the MIXED procedure (SAS Institute Inc.), with week of lactation (WOL) as the repeated effect, the spatial power law specified as the covariance structure, and block as a random effect. The model included effects of bST, diet, WOL, and their interactions. Results are reported as least squares means and were considered to differ when $P<0.05$. Trends were identified when $0.05<P<0.10$. Correlation and linear regression coefficients (CORR and REG procedures of SAS, respectively) were used to describe relationships between fatty acids in milk.

\section{RESULTS}

The AF diet contained less linoleic acid (18:2) and more linolenic acid (18:3), EPA, and DHA, and had a reduced $n-6 / n-3$ ratio relative to the SS diet (Table 1). These dietary alterations did not affect the amount of linoleic acid $(P=0.573)$ in milk fat, but there was more $(P<0.04)$ linolenic acid, EPA, and DHA in milk fat from cows fed AF than from cows fed SS (Table 2). Milk from cows fed AF also had more 4:0 $(P=0.019)$ and 20:0 $(P=0.005)$, less $14: 1(P=0.006)$, and a trend $(P=0.070)$ for less cis-9, trans-11 CLA, but the contribution of other fatty acids to milk fat was not altered by diet. Relative proportions of all fatty acids changed as lactation progressed, but only the changes in EPA and DHA were affected by an interaction $(P<0.003)$ of diet and WOL (Table 2, Figure 1). The contributions of EPA $(P<0.003)$ and DHA $(P<0.001)$ to milk fat increased as lactation progressed for cows fed AF but decreased (EPA) or remained constant (DHA) for cows fed SS. There were no interactions $(P>0.11)$ of diet and bST on proportion of any individual fatty acid. The only individual fatty acid altered by the interaction of 
Table 2. Effects of source of dietary fat, ${ }^{1}$ bST administration, and week of lactation on fatty acid composition of milk from multiparous Holstein cows

\begin{tabular}{|c|c|c|c|c|c|c|c|c|c|c|}
\hline $\begin{array}{l}\text { Fatty } \operatorname{acid}^{2}(\mathrm{mg} / \mathrm{g} \text { of } \\
\text { total fatty acids) }\end{array}$ & \multicolumn{4}{|c|}{ Treatment $^{3}$} & $\mathrm{SE}$ & \multicolumn{5}{|c|}{$P$-value ${ }^{4}$} \\
\hline 4:0 & 22.83 & 22.33 & 24.66 & 23.49 & 0.60 & 0.019 & 0.175 & 0.001 & 0.368 & 0.413 \\
\hline 8:0 & 10.61 & 10.12 & 11.26 & 10.19 & 0.64 & 0.579 & 0.235 & 0.001 & 0.329 & 0.009 \\
\hline 10:0 & 21.11 & 19.64 & 22.29 & 20.46 & 1.39 & 0.474 & 0.242 & 0.001 & 0.621 & 0.021 \\
\hline $12: 0$ & 23.11 & 21.70 & 23.43 & 21.82 & 1.43 & 0.880 & 0.296 & 0.001 & 0.463 & 0.017 \\
\hline $15: 0$ & 7.60 & 6.74 & 7.30 & 6.86 & 0.57 & 0.874 & 0.249 & 0.001 & 0.844 & 0.460 \\
\hline $16: 0$ & 243.86 & 234.87 & 252.46 & 241.63 & 7.11 & 0.280 & 0.167 & 0.001 & 0.162 & 0.308 \\
\hline $16: 1$ cis- 9 & 19.59 & 18.65 & 18.19 & 18.80 & 0.74 & 0.366 & 0.817 & 0.001 & 0.844 & 0.302 \\
\hline $17: 0$ & 5.52 & 5.44 & 5.85 & 5.98 & 0.25 & 0.092 & 0.912 & 0.001 & 0.543 & 0.082 \\
\hline 18:0 & 109.41 & 122.69 & 117.82 & 121.49 & 5.30 & 0.453 & 0.086 & 0.001 & 0.352 & 0.815 \\
\hline $18: 1$ trans $-6-8$ & 6.65 & 5.15 & 4.95 & 5.33 & 0.67 & 0.267 & 0.404 & 0.045 & 0.625 & 0.255 \\
\hline 18:1 trans -9 & 4.92 & 4.60 & 4.58 & 5.20 & 0.46 & 0.772 & 0.750 & 0.023 & 0.636 & 0.119 \\
\hline 18:2 cis -9, trans -11 (CLA) & 6.11 & 5.21 & 5.01 & 4.84 & 0.39 & 0.070 & 0.182 & 0.001 & 0.342 & 0.241 \\
\hline $18: 3$ cis -9, cis -12, cis -15 & 3.90 & 3.28 & 4.18 & 3.85 & 0.21 & 0.040 & 0.022 & 0.137 & 0.282 & 0.005 \\
\hline $20: 0$ & 0.87 & 1.01 & 1.11 & 1.08 & 0.05 & 0.005 & 0.280 & 0.762 & 0.258 & 0.105 \\
\hline 20:5 (EPA) & 0.42 & 0.41 & 0.53 & 0.51 & 0.03 & 0.003 & 0.650 & 0.040 & 0.003 & 0.969 \\
\hline 22:6 (DHA) & 0.03 & 0.01 & 0.13 & 0.09 & 0.02 & 0.001 & 0.186 & 0.001 & 0.001 & 0.165 \\
\hline Unknown $^{5}$ & 43.80 & 44.50 & 44.53 & 47.02 & 1.89 & 0.397 & 0.404 & 0.048 & 0.282 & 0.730 \\
\hline
\end{tabular}

${ }^{1}$ Cows were fed whole, high-oil sunflower seeds (SS, n-6/n-3 fatty acids = 4.6) or a mixture of Alifet-High Energy and Alifet-Repro (AF; Alifet USA, Cincinnati, OH; n- $6 / \mathrm{n}-3$ fatty acids $=2.6$ ).

${ }^{2} \mathrm{VA}=$ vaccenic acid; CLA = conjugated linoleic acid; $\mathrm{EPA}=$ eicosapentaenoic acid; DHA = docosahexaenoic acid.

${ }^{3}$ Data represent least squares means from treatments derived from a $2 \times 2$ combination of supplemental fat source (SS, AF) beginning at calving and with 0 (SSN, AFN) or 500 (SSY, AFY) mg of bST administered every $10 \mathrm{~d}$ from 12 to 70 DIM and at 14-d intervals thereafter. Data were collected from 32 cows (8 complete blocks).

${ }^{4} \mathrm{D}=$ diet; $\mathrm{B}=\mathrm{bST} ; \mathrm{W}=$ week of lactation. There were no $\mathrm{D} \times \mathrm{B}$ interactions. Only $\mathrm{DHA}$ had a $\mathrm{D} \times \mathrm{B} \times \mathrm{W}$ interaction $(P=0.028)$.

${ }^{5}$ Unidentified fatty acids.

diet, bST, and WOL was DHA $(P=0.028)$, which was not altered by WOL in cows fed SS and increased at 8 and $20 \mathrm{WOL}$ in AFN and AFY cows, respectively.

Yield of $3.5 \%$ FCM $(41.7,48.0,43.3$, and $47.2 \mathrm{~kg} / \mathrm{d}$ for $\mathrm{SSN}, \mathrm{SSY}, \mathrm{AFN}$, and AFY, respectively) was increased $(P=0.001)$ by bST, and this effect became more apparent $(P=0.019)$ as lactation progressed (Carriquiry et al., 2009). There were no effects or interaction of diet $\times$ bST administration on milk fat content (3.89, 4.22 , 4.12, and $4.19 \%$ for SSN, SSY, AFN, and AFY, respectively; Carriquiry et al., 2009). The proportions of 6:0 and 14:0 in milk were reduced $(P<0.05)$ by bST (Table 2). These reductions were temporary, however, because proportions of these fatty acids and of total de novo fatty acids did not differ between bST-treated and untreated cows by 20 WOL (Figures 2 and 3). Total trans fatty acid concentration in milk $(40.02 \pm 3.05$ $\mathrm{mg} / \mathrm{g}$ of fatty acids) did not differ among treatments $(P>0.15$; data not presented $)$ and was not affected by WOL $(P>0.23)$, but the overall proportion of VA in milk fat decreased $(P=0.031)$ by 8 WOL $(15.0$,
12.7 , and $12.1 \pm 0.7 \mathrm{mg} / \mathrm{g}$ of fatty acids for WOL 2 , 8 , and 20, respectively). Milk fat cis-9, trans-11 CLA concentration (Table 2$)$ increased $(P<0.001)$ by 1.5 $\mathrm{mg} / \mathrm{g}$ from 2 to 8 WOL $(4.3,5.8$, and $5.8 \pm 0.3 \mathrm{mg} / \mathrm{g}$ of fatty acids for WOL 2,8 , and 20, respectively). Stearic acid content of milk fat decreased $(P=0.001)$ through 8 WOL (Figure 2). Administration of bST increased $(P$ $<0.001$ ) the overall proportion of oleic acid in milk fat, but this was the result of a bST-induced delay (interaction, $P=0.005)$ in the decrease $(P=0.001)$ of oleic acid as lactation progressed (Table 2, Figure 2). Cows treated with bST produced milk with less $(P=0.022)$ linolenic acid (Figure 2). Although there was no effect of WOL on linolenic acid, there was an interaction $(P$ $=0.005)$ of bST and WOL because the bST-induced decrease in linolenic acid occurred only at 8 WOL.

The proportion of total de novo-synthesized and mixed-origin $(16: 0+16: 1)$ fatty acids increased $(P<$ $0.001)$, whereas total preformed $(>17: 0)$ fatty acids decreased $(P<0.001)$ as lactation progressed from 2 to 20 WOL (Table 3, Figure 3). Similar changes were 
A

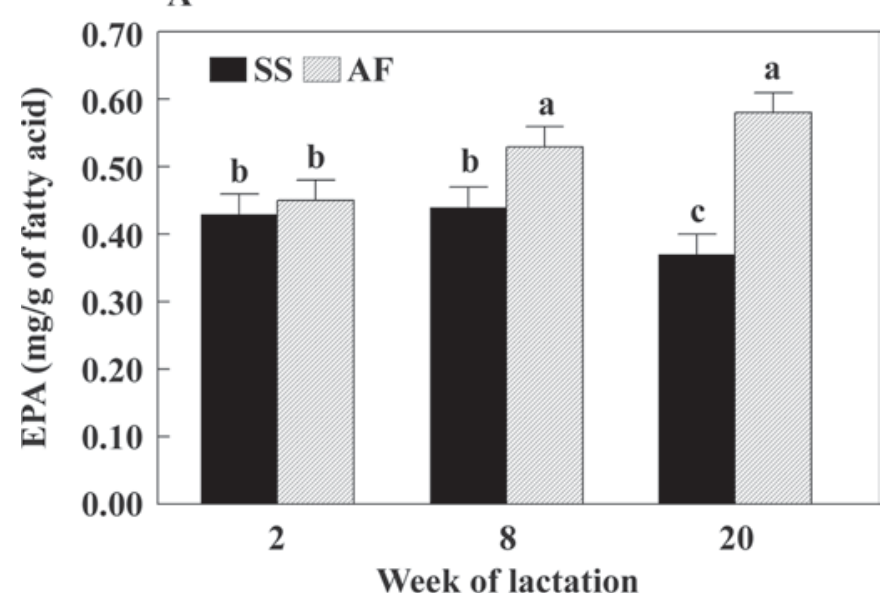

B

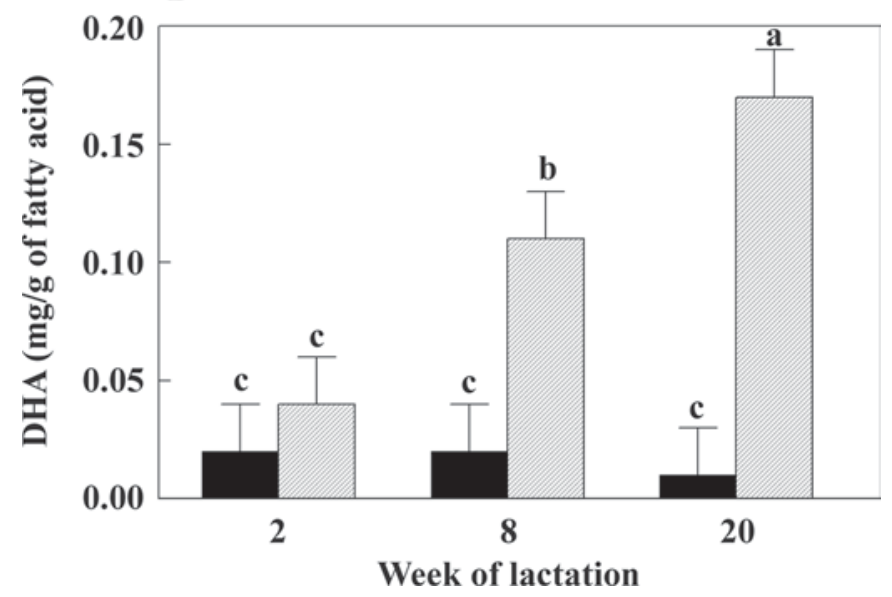

Figure 1. Effect of source of dietary fat and week of lactation on milk eicosapentaenoic (EPA) and docosahexaenoic (DHA) acids. Data are least squares means from 8 blocks of 4 cows $(n=32)$. Cows were fed diets that contained whole, high-oil sunflower seeds (SS; n-6/n-3 fatty acid ratio $=4.6 ; \mathrm{n}=16$ ) or a mixture of Alifet-High Energy and Alifet-Repro (AF; Alifet USA, Cincinnati, OH; n-6/n-3 fatty acid ratio $=2.6 ; \mathrm{n}=16$ ) from calving. ${ }^{\mathrm{a}-\mathrm{c}}$ Letters indicate an interaction of fat source and week of lactation for EPA $(P=0.003)$ and DHA $(P=0.001)$. Milk content of these fatty acids was not affected $(P>$ 0.186 ) by administration of $500 \mathrm{mg}$ of bST every $10 \mathrm{~d}$ from 12 to 70 DIM and at 14-d intervals thereafter in this factorial arrangement of treatments.

detected for most individual fatty acids (Table 2, Figure 2). The increase in total de novo fatty acids ( $\mathrm{y}=$ $\left.147+4.6 \mathrm{x}, \mathrm{r}^{2}=0.48, P<0.001\right)$ and the reduction in total preformed fatty acids $\left(\mathrm{y}=606-6.0 \mathrm{x}, \mathrm{r}^{2}=0.42\right.$, $P<0.001)$ were linear when cows were not treated with bST, but there were interactions of bST and WOL because an increase $(P=0.023)$ in de novo-synthesized fatty acids occurred at 20 rather than 8 WOL when cows were treated with bST (Figure 3).

The proportion of SFA, monounsaturated fatty acids (MUFA), and PUFA and the SFA-to-UFA ratio were not affected by diet $(P>0.14$; Table 3$)$. There was an interaction of bST and WOL on the proportion of SFA $(P=0.004)$ and MUFA $(P=0.004)$ and the SFA-toUFA ratio $(P=0.014)$ because an increase in SFA, a decrease in MUFA, and an increase in the SFA-to-UFA ratio occurred by 8 WOL in untreated cows and did not occur until later in lactation when cows were treated with bST. These profiles (data not presented) were similar to those in Figures 2 and 3.

As expected, the n- $6 / \mathrm{n}-3$ fatty acid ratio in milk was reduced $(P=0.002)$ for cows fed AF (8.8 vs. $7.4 \pm 0.3$; Table 3 , Figure $4 \mathrm{~A})$, and there was a trend $(P=0.060)$ for this difference to increase as lactation progressed. Although there was no effect of bST $(P=0.254)$, there was an interaction of $\mathrm{bST}$ and WOL $(P=0.04)$ on the n-6/n-3 fatty acid ratio because the ratio was greater at 8 than at 2 WOL $(7.9,8.9$, and $8.2 \pm 0.4 \mathrm{mg} / \mathrm{g}$ of fatty acids for WOL 2, 8, and 20, respectively) but remained unchanged $(8.1,7.8$, and $7.7 \pm 0.4 \mathrm{mg} / \mathrm{g}$ of fatty acids for WOL 2,8 , and 20, respectively) in cows not treated with bST (Figure 4).

The product-to-substrate ratio of 14:1/14:0 fatty acids $(0.096$ vs. $0.082 \pm 0.005)$ was greater $(P<0.002)$ in milk from cows fed SS than those fed AF and was not affected $(P>0.76)$ by bST administration, but there was an interaction $(P=0.024)$ of bST and diet because the ratio decreased in bST-treated cows fed SS but increased in bST-treated cows fed AF (Table 3). The overall ratio of 14:1/14:0 fatty acids increased $(P$ $=0.001)$ from 2 to 8 WOL $(0.077,0.092$, and $0.098 \pm$ 0.006 for WOL 2, 8, and 20, respectively). The cis-9, trans-11 CLA-to-VA ratio increased $(P<0.001)$ in a manner similar to WOL $(0.30,0.46$, and $0.50 \pm 0.01$ for WOL 2, 8, and 20, respectively). Other productto-substrate ratios and the apparent $\Delta^{9}$-desaturase activity provided less consistent results. Although all of the product-to-substrate ratios were affected by WOL $(P<0.001$; Table 3$)$, the response varied among the product-substrate pairs (data not presented). During the first $20 \mathrm{WOL}$ (independent of treatments and sampling times), cis-9, trans-11 CLA in milk fat was correlated with milk fat VA $(\mathrm{r}=0.39, P<0.001$; Figure $5 \mathrm{~A})$ and with apparent $\Delta^{9}$-desaturase activity based on the 14:1/14:0 fatty acid ratio $(\mathrm{r}=0.47 ; P<0.001$; Figure 5B).

Overall transfer efficiency of linolenic acid, EPA, and DHA from the AF diet to milk fat averaged 36.2, 4.9, and $5.2 \%$, respectively. Transfer efficiencies of these fatty acids decreased with administration of bST (40.4 vs. $29.3 \%, 5.0$ vs. $3.9 \%$, and 5.3 vs. $4.0 \%$ for linolenic acid, EPA, and DHA without and with bST, respectively). As lactation progressed from 2 to 20 WOL, transfer efficiencies increased from 27.9 to $74.5 \%$ for linolenic acid, 2.2 to $8.6 \%$ for EPA, and 1.7 to $7.6 \%$ for DHA (Figure 6). 

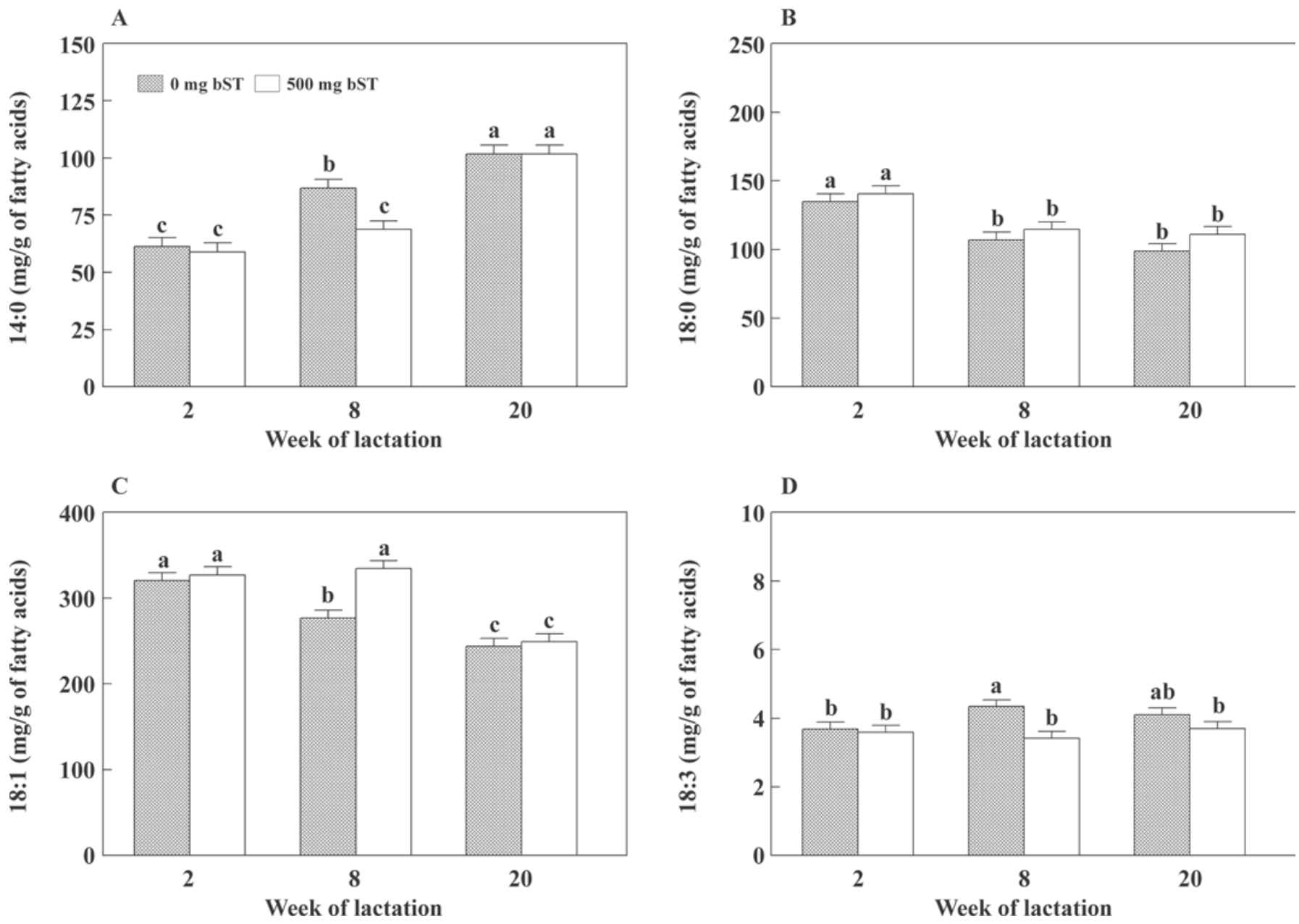

Figure 2. Effect of bST administration and week of lactation on concentrations of 14:0 (A), 18:0 (B), cis-9 18:1 (C), and cis-9, cis-12, cis-15 18:3 (D) in milk fat. Data are least squares means from 8 blocks of 4 cows $(n=32)$. Cows were fed diets that contained whole, high-oil sunflower seeds or a mixture of Alifet-High Energy and Alifet-Repro (Alifet USA, Cincinnati, OH) from calving. Cows were either not treated $(\mathrm{n}=16)$ or treated $(\mathrm{n}=16)$ with $500 \mathrm{mg}$ of bST every $10 \mathrm{~d}$ from 12 to 70 DIM and at 14 -d intervals thereafter. ${ }^{\mathrm{a}-\mathrm{c}}$ Letters indicate an interaction of bST and week of lactation for 14:0 $(P=0.034)$, cis-9 18:1 $(P=0.005)$, and cis-9, cis-12, cis-15 18:3 $(P=0.005)$ and a week of lactation effect for 18:0 $(P=0.001)$.

\section{DISCUSSION}

Our results indicate that the increased yields of milk fat by bST-treated cows in early lactation were attained through a greater mammary extraction of preformed fatty acids from the blood, with a proportionally reduced contribution of short-chain fatty acids. However, both total de novo synthesis and total extraction of preformed fatty acids were enhanced because bST increased the yield of each individual fatty acid. The increased incorporation of preformed fatty acids could occur through increased efficiency of utilization of consumed lipids, increased mobilization of tissue lipids, or increased use of dietary and tissue sources of fatty acids. Similar results usually occurred when cows were treated with bST in early (Lormore et al., 1990) or mid- to late (Eppard et al., 1985) lactation. The peak rate of tissue mobilization usually occurs in early lactation, when the contribution of preformed fatty acids to milk fat should be the greatest (Palmquist et al., 1993). Our results support this because the preformed fatty acids represented $59 \%$ of total fatty acids at 2 WOL and decreased in a linear manner from 2 to 20 WOL when cows were not treated with bST. In contrast, the proportion of preformed fatty acids in milk from bSTtreated cows remained stable $(59 \%)$ through 8 WOL and decreased by $16 \%$ from 8 to 20 WOL. Thus, although preformed fatty acids in milk from bST-treated and nontreated cows represented similar proportions of the total fatty acids at 2 and 20 WOL (59 and 49\%, respectively), the onset of this decrease was delayed by bST administration. The greater contribution of pre- 
A

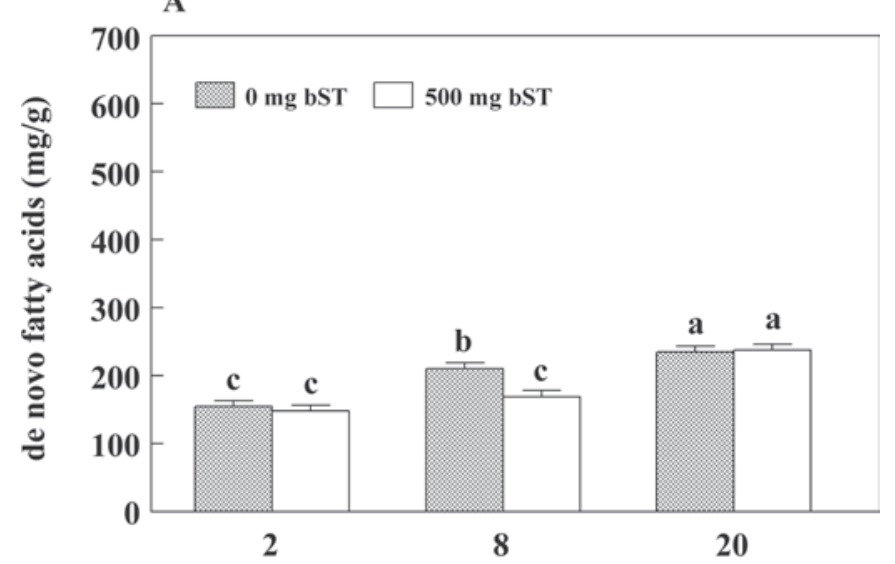

B
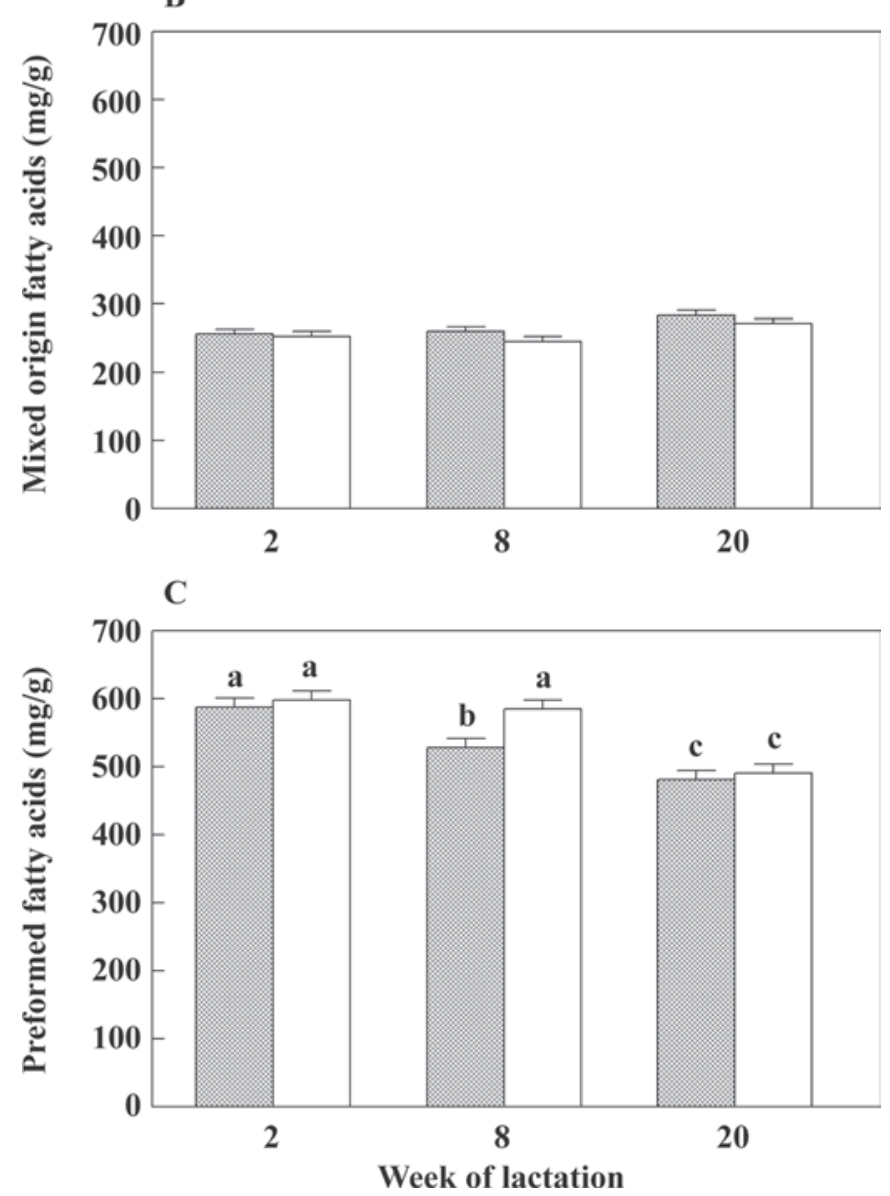

Figure 3. Effect of bST administration and week of lactation on milk fatty acid origin. Origins were calculated as A) de novo (4:0 to 15:0), B) mixed-origin $(16: 0+16: 1)$, and C) preformed $(\geq 17: 0)$ fatty acids. Data are least squares means from 8 blocks of 4 cows $(n=32)$. Cows were fed diets that contained whole, high-oil sunflower seeds or a mixture of Alifet-High Energy and Alifet-Repro (Alifet USA, Cincinnati, $\mathrm{OH})$ from calving. Cows were either not treated $(\mathrm{n}=16)$ or treated $(\mathrm{n}=16)$ with $500 \mathrm{mg}$ of bST every $10 \mathrm{~d}$ from 12 to 70 DIM and at 14-d intervals thereafter. ${ }^{\mathrm{a}-\mathrm{c}}$ Letters indicate an interaction of $\mathrm{bST}$ and week of lactation for de novo $(P<0.023)$ and preformed $(P$ $=0.054)$ fatty acids. Proportions of de novo, mixed-origin, and preformed fatty acids in milk fat did not differ $(P>0.50)$ between diets. formed fatty acids in milk from our bST-treated cows at 8 WOL was attributable primarily to increased cis-9 18:1, which represented $33 \%$ of total fatty acids at 2 and 8 WOL. Oleic acid was present in the SS (24\%) and AF $(13 \%)$ diets, is a predominant preformed fatty acid in adipocytes, and is the primary fatty acid released from adipocytes during lipolysis (Rukkwamsuk et al., 2000). Therefore, whether the bST-induced delay in the reduced contribution of preformed fatty acids to milk fat was due to greater use of fatty acids from tissue sources, dietary sources, or a combination of both sources cannot be assessed from our results.

Feeding unprotected UFA produced unique biohydrogenation intermediates that inhibited mammary fatty acid synthesis, increased the proportion of preformed fatty acids in milk, and decreased fat content of milk (Bauman et al., 2008). These effects were reduced when UFA were protected and when diets contained a large proportion of forage as grass silage or alfalfa (Chilliard et al., 2001). The whole sunflower seeds and microcrystallized Alifet-Repro in our study provided UFA that were at least partially protected from rumen microbial metabolism, and alfalfa haylage represented $50 \%$ of dietary forage. These conditions probably limited the formation and escape from the rumen of fatty acids that depress milk fat and might help explain why the proportions of de novo-synthesized and preformed fatty acids in milk did not differ between our diets. This premise is at least partially supported by the lack of an effect of diet on the proportion of trans-10 18:1 in milk fat from our cows. This trans-18:1 isomer does not cause milk fat depression but has been associated closely with the fat content of milk (Bauman et al., 2008).

Differences in fatty acid composition of the SS and $\mathrm{AF}$ diets and the protection provided by Alifet-Repro (Carriquiry et al., 2008) increased linolenic acid, EPA, and DHA and decreased the n-6/n-3 fatty acid ratio in milk when cows consumed AF. Several studies (Mattos et al., 2000; Petit et al., 2004) have demonstrated that a decreased dietary $n-6 / n-3$ fatty acid ratio can reduce the n-6/n-3 fatty acid ratio in milk fat. Bilby et al. (2006) reported a decreased n-6/n-3 fatty acid ratio in milk fat and in endometrial, liver, muscle, and mammary tissue when cows were fed a diet enriched in EPA and DHA from fish oil.

Transfer efficiencies of EPA (2 to 3.7\%) and DHA (1.8 to $5.1 \%$ ) from feed to milk fat were low when cows were fed unprotected fish or sunflower oils (Chilliard et al., 2001; Shingfield et al., 2006) or calcium salts of fish oils (Castañeda-Gutiérrez et al., 2007) but were increased (18 to $33 \%$ for EPA and 16 to $25 \%$ for DHA) when the oils were infused postruminally (Chilliard et al., 2001; Castañeda-Gutiérrez et al., 2007) or fed in a rumen- 


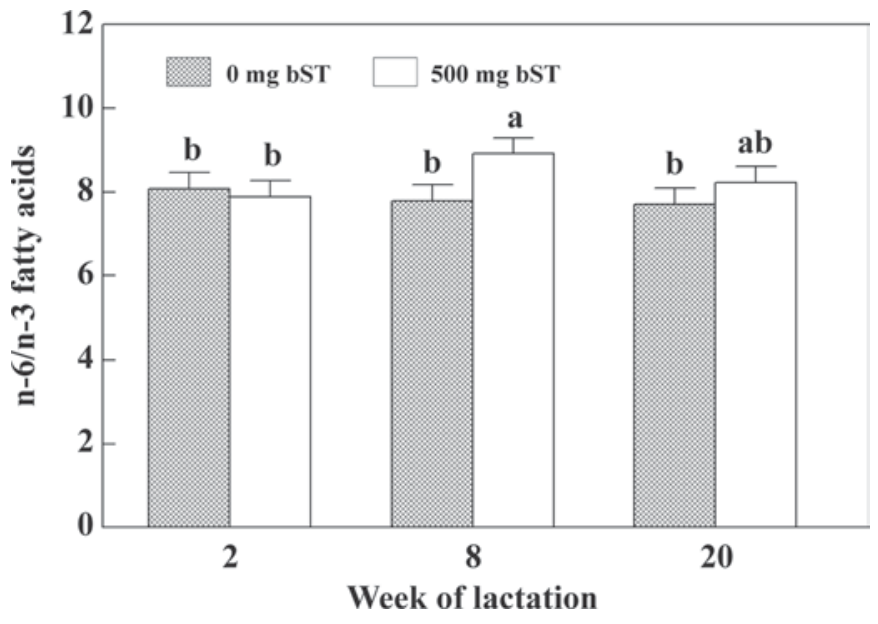

Figure 4. Effect of bST administration and week of lactation on the $n-6 / n-3$ fatty acid ratio in milk fat. Data are least squares means from 8 blocks of 4 cows $(n=32)$. Cows were fed diets that contained whole, high-oil sunflower seeds $(\mathrm{n}-6 / \mathrm{n}-3$ fatty acid ratio $=4.6 ; \mathrm{n}=$ 16) or a mixture of Alifet-High Energy and Alifet-Repro (Alifet USA, Cincinnati, $\mathrm{OH} ; \mathrm{n}-6 / \mathrm{n}-3$ fatty acid ratio $=2.6 ; \mathrm{n}=16$ ) from calving. Cows were either not treated $(\mathrm{n}=16)$ or treated $(\mathrm{n}=16)$ with $500 \mathrm{mg}$ of bST every $10 \mathrm{~d}$ from 12 to 70 DIM and at 14-d intervals thereafter. ${ }^{\mathrm{a}, \mathrm{b}}$ Letters indicate an interaction $(P=0.038)$ of $\mathrm{bST}$.

protected form (Kitessa et al., 2004). We determined that 90 to $95 \%$ of the EPA and DHA in Alifet-Repro remained intact after in vitro incubation with rumen microorganisms for $36 \mathrm{~h}$ (Carriquiry et al., 2008), which indicated these n-3 PUFA were protected from metabolism in the rumen. Although EPA and DHA transfer efficiencies from AF averaged approximately $5 \%$ in our study and were less than those obtained when tuna oil was protected with formaldehyde (Kitessa et al., 2004), they were greater than those obtained when unaltered fish or sunflower oils were fed to lactating cows (Chilliard et al., 2001; Shingfield et al., 2006).

Transfer efficiencies of dietary EPA and DHA to milk fat in our cows increased from $2 \%$ at 2 WOL to approximately $8 \%$ at 20 WOL. Shingfield et al. (2006) demonstrated that after an initial increase, EPA and DHA content in milk from midlactation cows (170 DIM) fed fish and sunflower oil decreased and remained relatively stable from d 16 to 28 of treatment. These authors suggested that the reduction in transfer efficiency could be due to a progressive increase in the extent of EPA and DHA metabolism by ruminal microorganisms or could reflect an increased incorporation of these fatty acids into microbial cell membrane phospholipids. Our results indicate that other adaptations (likely postruminal) occurred after prolonged treatment to increase the efficiency of transfer. Lock and Bauman (2004) indicated that additional constraints to feeding EPA and DHA included the fact that these 2 n-3 PUFA were not transported primarily in the plasma lipid fractions (triglycerides and NEFA) that serve as major sources

Table 3. Effects of source of dietary fat, ${ }^{1}$ bST administration, and week of lactation on fatty acid components of milk from multiparous Holstein cows

\begin{tabular}{|c|c|c|c|c|c|c|c|c|c|c|c|}
\hline Variable & \multicolumn{4}{|c|}{ Treatment $^{2}$} & SE & \multicolumn{6}{|c|}{$P$-value ${ }^{3}$} \\
\hline \multicolumn{12}{|l|}{ Fatty acid origin (mg/g of fatty acids) } \\
\hline Mixed origin $(16: 0+16: 1)$ & 263.44 & 253.53 & 270.65 & 260.34 & 7.28 & 0.339 & 0.173 & 0.979 & 0.001 & 0.218 & 0.514 \\
\hline Preformed $(>17: 0)$ & 537.59 & 561.65 & 528.25 & 554.23 & 12.63 & 0.512 & 0.056 & 0.940 & 0.001 & 0.139 & 0.054 \\
\hline \multicolumn{12}{|l|}{$\begin{array}{l}\text { Fatty acid saturation } \\
\text { (mg/g of fatty acids) }\end{array}$} \\
\hline Monounsaturated & 358.52 & 372.49 & 339.88 & 361.42 & 9.95 & 0.145 & 0.084 & 0.706 & 0.001 & 0.166 & 0.004 \\
\hline Polyunsaturated & 47.57 & 41.37 & 43.91 & 42.34 & 2.54 & 0.587 & 0.125 & 0.353 & 0.001 & 0.899 & 0.502 \\
\hline Saturated/unsaturated & 1.41 & 1.35 & 1.54 & 1.41 & 0.07 & 0.200 & 0.192 & 0.635 & 0.001 & 0.100 & 0.014 \\
\hline \multirow{2}{*}{\multicolumn{12}{|c|}{$\Delta^{9}$-Desaturase ratio and index }} \\
\hline & & & & & & & & & & & \\
\hline $14: 1 / 14: 0$ & 0.101 & 0.091 & 0.078 & 0.086 & 0.006 & 0.002 & 0.761 & 0.024 & 0.001 & 0.114 & 0.498 \\
\hline $16: 1 / 16: 0$ & 0.082 & 0.080 & 0.073 & 0.079 & 0.004 & 0.197 & 0.586 & 0.349 & 0.001 & 0.685 & 0.178 \\
\hline
\end{tabular}

${ }^{1}$ Cows were fed whole, high-oil sunflower seeds (SS; n-6/n-3 fatty acids = 4.6) or a mixture of Alifet-High Energy and Alifet-Repro (AF; Alifet USA, Cincinnati, OH; n-6/n-3 fatty acids = 2.6).

${ }^{2}$ Data represent least squares means for treatments derived from a $2 \times 2$ combination of supplemental fat source (SS, AF) beginning at calving and with 0 (SSN, AFN) or 500 (SSY, AFY) mg of bST administered every $10 \mathrm{~d}$ from 12 to 70 DIM and at 14-d intervals thereafter. Data were collected from 32 cows (8 complete blocks).

${ }^{3} \mathrm{D}=$ diet; $\mathrm{B}=\mathrm{bST} ; \mathrm{W}=$ week of lactation. There was no $\mathrm{D} \times \mathrm{B} \times \mathrm{W}$ interaction $(P>0.20)$ for any variable.

${ }^{4}$ Calculated from $(14: 1+16: 1+$ cis-9 18:1 + cis-9, trans-11 CLA)/(14:0 + 16:0 + 18:0 + trans-11 18:1 + 14:1 + 16:1 + cis-9 18:1 + cis-9, trans-11 18:2). 

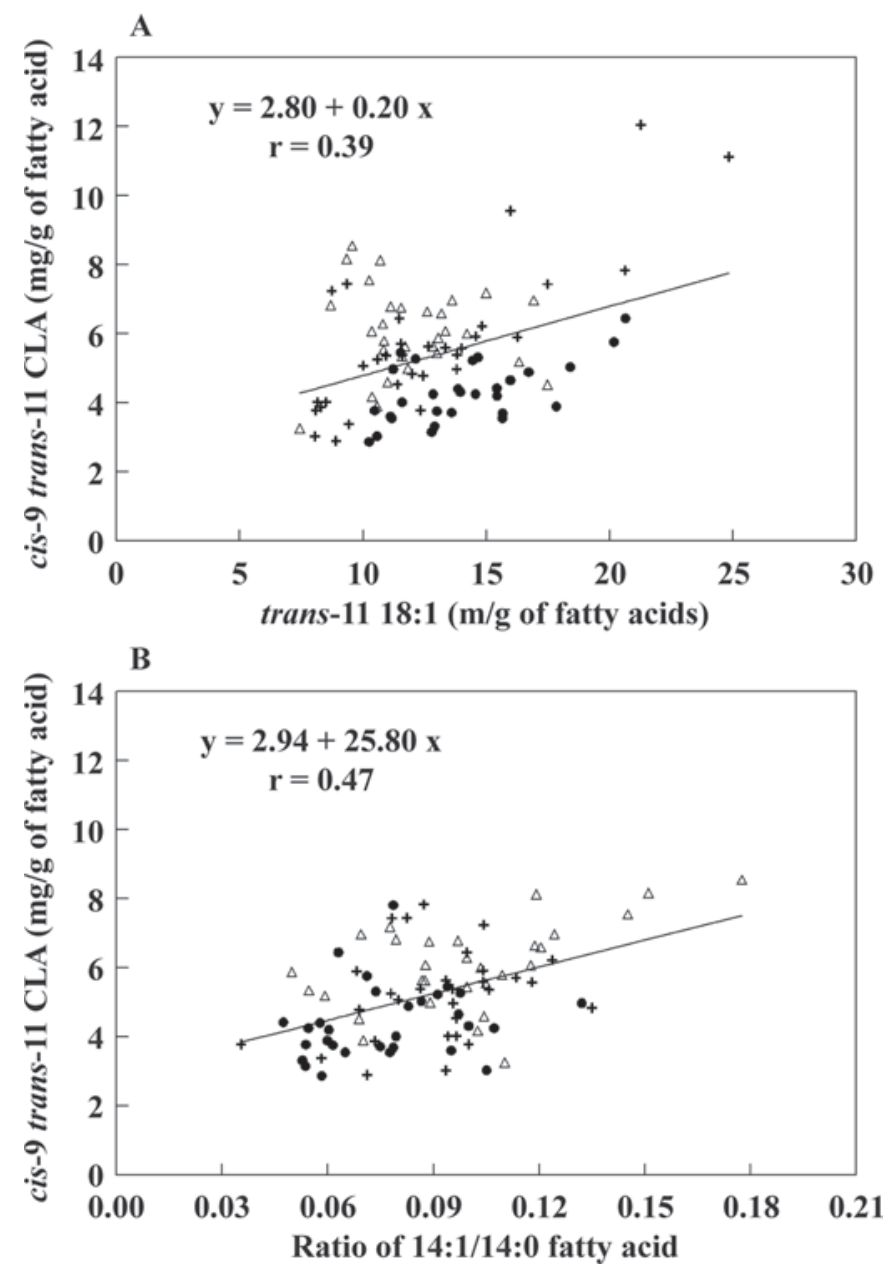

Figure 5. Relationship between cis-9, trans-11 18:2 conjugated linoleic acid (CLA) and trans-11 18:1 (A) and the ratio of 14:1/14:0 fatty acids (B) in milk fat. Regression equations were derived from data obtained during wk $2(\bullet), 8(+)$, and $20(\Delta)$ of lactation from 8 blocks of 4 cows $(n=32)$. The product-to-substrate ratio of 14:1/14:0 represents activity of the $\Delta^{9}$-desaturase system in the mammary gland.

of fatty acids for mammary uptake and this contributed to their limited incorporation into milk fat. Bilby et al. (2006) fed cows a calcium salt of a fish oil-enriched lipid product and reported that accumulation and distribution of EPA and DHA varied among milk and several body tissues (liver, endometrium, mammary gland, subcutaneous adipose, and internal adipose). Their results indicated that incorporation of EPA and DHA (and presumably other n-3 PUFA) into body tissues was variable and that accumulation in milk fat did not necessarily reflect whole-body availability of these fatty acids or the potential impact these fatty acids might have had on extramammary tissues.

Milk fat cis-9, trans-11 CLA content tended to be less when our cows consumed AF (more linolenic and other n-3 PUFA) than when they consumed SS (more linoleic and other n-6 PUFA). The cis-9, trans-11 CLA in milk fat originates from incomplete biohydrogenation of PUFA with about 10 to $30 \%$ of the cis-9, trans-11 CLA being absorbed from the digestive tract and incorporated directly into milk fat. The majority (70 to $90 \%$ ) of cis-9, trans-11 CLA in milk fat originates from conversion of absorbed VA to cis-9, trans-11 CLA by mammary $\Delta^{9}$-desaturase (Bauman et al., 2006). Although several associated pair ratios and an overall $\Delta^{9}$-desaturase index can be computed, Peterson et al. (2002) suggest the 14:1/14:0 ratio most likely represents the best proxy for apparent $\Delta^{9}$-desaturase activity (a combination of specific activity and quantity of enzyme) in the mammary gland. In our cows, VA content of milk fat and the 14:1/14:0 estimate of mammary $\Delta^{9}$-desaturase activity were associated directly with increased amounts of cis-9, trans-11 CLA in milk fat.

Apparent mammary $\Delta^{9}$-desaturase activity was increased by bST when our cows were fed AF and was decreased by bST when cows were fed SS. In contrast, apparent mammary $\Delta^{9}$-desaturase activity decreased when bST-treated cows consumed a diet that contained a calcium salt of fish oil and increased when bST-treated cows consumed a diet that contained whole cottonseed (Bilby et al., 2006). These results suggest that the effect of bST depends on the diet being fed and that the effect may be influenced by the type and distribution of fatty acids presented to the mammary gland.

Our results support those of previous studies that demonstrated small increases in milk cis-9, trans-11 CLA and apparent mammary $\Delta^{9}$-desaturase activity in

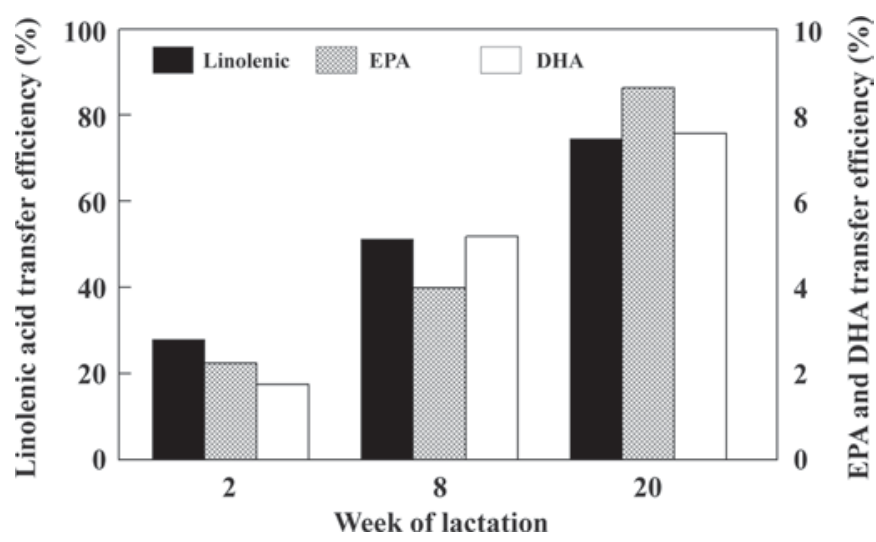

Figure 6. Effect of week of lactation on the transfer efficiency of linolenic acid, eicosapentaenoic acid (EPA), and docosahexaenoic acid (DHA) from Alifet-Repro (Alifet USA, Cincinnati, OH) to milk fat. Transfer efficiencies were obtained from cows fed whole, high-oil sunflower seeds or a mixture of Alifet-High Energy (Alifet USA) and Alifet-Repro and treated with 0 or $500 \mathrm{mg}$ of bST every $10 \mathrm{~d}$ from 12 to 70 DIM and at 14-d intervals thereafter. Transfer efficiencies decreased with administration of bST (40.4 vs. $29.3 \%, 5.0$ vs. $3.9 \%$, and 5.3 vs. $4.0 \%$ for linolenic acid, EPA, and DHA without and with bST, respectively). 
early lactation (Kay et al., 2005). The largest increases in cis-9, trans-11 CLA content of milk fat and in apparent mammary $\Delta^{9}$-desaturase activity in our current study occurred between 2 and 8 WOL. Milk cis-9, trans-11 CLA and apparent mammary $\Delta^{9}$-desaturase activity increased through at least 16 WOL (Kay et al., 2005), but appeared to plateau by 8 WOL in the current study. These increases in milk cis-9, trans-11 CLA content in our current (35\%) and previous (75\%; Kay et al., 2005) studies were not influenced by a change in dietary components because all cows consumed a consistent diet at least through the interval of analysis. Nonetheless, this early-lactation increase in milk cis-9, trans-11 CLA was relatively small compared with the increase (up to 4-fold) obtained when diets were modified to include specific oils or greater amounts of fresh forage (Bauman et al., 2006).

\section{CONCLUSIONS}

Consumption of Alifet-Repro by lactating cows increased n-3 fatty acids, particularly EPA and DHA, and reduced the $n-6 / n-3$ fatty acid ratio in milk. Although these relatively small changes could prove beneficial to animal health, these benefits were potentially offset by a trend for reduced cis-9, trans-11 CLA in milk from cows that consumed Alifet-Repro. Administration of bST in early lactation prolonged the priority to partition dietary fatty acids into milk fat and interacted with dietary fat to alter apparent mammary $\Delta^{9}$-desaturase activity. There was an overall modest increase in milk cis-9, trans-11 CLA content at least through 8 WOL, and this was associated with a similar increase in apparent mammary $\Delta^{9}$-desaturase activity.

\section{ACKNOWLEDGMENTS}

The authors thank Sara R. Sanders (Department of Animal Sciences, University of Arizona, Tucson) for her technical expertise and skill in performing the fatty acid analyses. We also thank Monsanto Co. (St. Louis, $\mathrm{MO}$ ) for providing the recombinant bST (Posilac) and Alifet USA (Cincinnati, OH) for providing the AlifetHigh Energy and Alifet-Repro. Excellent animal care and courteous assistance throughout the study were provided by the staff at the University of Minnesota, Northwest Research and Outreach Center (Crookston, $\mathrm{MN})$.

\section{REFERENCES}

Bauman, D. E., A. L. Lock, B. A. Corl, C. Ip, A. M. Salter, and P. W. Parodi. 2006. Milk fatty acids and human health: Potential role of conjugated linoleic acid and trans fatty acids. Pages 529-551 in Ruminant Physiology: Digestion, Metabolism and Impact of
Nutrition on Gene Expression, Immunology and Stress. K. Sejrsen, T. Hvelplund, and M. O. Nielsen, ed. Wageningen Academic Publishers, Wageningen, the Netherlands.

Bauman, D. E., J. M. Perfield II, K. J. Harvatine, and L. H. Baumgard. 2008. Regulation of fat synthesis by CLA: Lactation and the ruminant model. J. Nutr. 38:403-409.

Bauman, D. E., and R. G. Vernon. 1993. Effects of exogenous bovine somatotropin on lactation. Annu. Rev. Nutr. 13:437-461.

Bilby, T. R., T. Jenkins, C. R. Staples, and W. W. Thatcher. 2006. Pregnancy, bST, and n-3 fatty acids in lactating dairy cows: III. Fatty acid distribution. J. Dairy Sci. 89:3386-3399.

Carriquiry, M., W. J. Weber, C. R. Dahlen, G. C. Lamb, L. H. Baumgard, and B. A. Crooker. 2009. Production response of multiparous Holstein cows treated with bovine somatotropin and fed diets enriched with n-3 or n-6 fatty acids. J. Dairy Sci. 92:4852-4864

Carriquiry, M., W. J. Weber, S. R. Sanders, L. H. Baumgard, and B. A. Crooker. 2008. In vitro biohydrogenation of protected dietary fats. Anim. Feed Sci. Technol. 141:339-355.

Castañeda-Gutiérrez, E., M. J. de Veth, A. L. Lock, D. A. Dwyer, K. D. Murphy, and D. E. Bauman. 2007. Effect of supplementation with calcium salts of fish oil on n-3 fatty acids in milk fat. J. Dairy Sci. 90:4149-4156

Chilliard, Y., A. Ferlay, and M. Doreau. 2001. Effect of different types of forages, animal fat or marine oils in cow's diet on milk fat secretion and composition, especially conjugated linoleic acid (CLA) and polyunsaturated fatty acids. Livest. Prod. Sci. 70:31-48.

Chouinard, P. Y., L. Corneau, A. Saebo, and D. E. Bauman. 1999 Milk yield and composition during abomasal infusion of CLA. J. Dairy Sci. 82:2737-2745.

Christie, W. W. 1982. A simple procedure for rapid transmethylation of glycerolipids and cholesteryl esters. J. Lipid Res. 23:10721075 .

Eppard, P. J., D. E. Bauman, J. Bitman, D. L. Wood, R. M. Akers, and W. A. House. 1985. Effect of dose of bovine growth hormone on milk composition: $\alpha$-Lactalbumin, fatty acids, and mineral elements. J. Dairy Sci. 68:3047-3054.

Griinari, J. M., D. A. Dwyer, M. A. McGuire, D. E. Bauman, D. L. Palmquist, and K. V. V. Nurmela. 1998. Trans-octadecenoic acids and milk fat depression in lactating dairy cows. J. Dairy Sci. 81:1251-1261

Hara, A., and N. S. Radin. 1978. Lipid extraction of tissues with a low-toxicity solvent. Anal. Biochem. 90:420-426.

Kang, J. X. 2005. From fat to fat-1: A tale of omega-3 fatty acids. J. Membr. Biol. 206:165-172.

Kay, J. K., W. J. Weber, C. E. Moore, D. E. Bauman, L. B. Hansen, H. Chester-Jones, B. A. Crooker, and L. H. Baumgard. 2005. Effects of week of lactation and genetic selection for milk yield on milk fatty acid composition in Holstein cows. J. Dairy Sci. 88:3886-3893.

Kitessa, S. M., S. K. Gulati, G. C. Simos, J. R. Ashes, T. W. Scott, E. Fleck, and P. C. Wynn. 2004. Supplementation of grazing dairy cows with rumen-protected tuna oil enriches milk fat with n-3 fatty acids without affecting milk production or sensory characteristics. Br. J. Nutr. 91:271-278.

Lessard, M., N. Gagnon, D. L. Godson, and H. V. Petit. 2004. Influence of parturition and diets enriched in $\mathrm{n}-3$ or $\mathrm{n}-6$ polyunsaturated fatty acids on immune response of dairy cows during the transition period. J. Dairy Sci. 87:2197-2210.

Lock, A. L., and D. E. Bauman. 2004. Modifying milk fat composition of dairy cows to enhance fatty acids beneficial to human health. Lipids 39:1197-1206.

Lormore, M. J., L. D. Muller, D. R. Deaver, and L. C. Griel Jr. 1990. Early lactation responses of dairy cows administered bovine somatotropin and fed diets high in energy and protein. J. Dairy Sci. 73:3237-3247.

Mansbridge, R. J., and J. S. Blake. 1997. Nutritional factors affecting the fatty acid composition of bovine milk. Br. J. Nutr. 78:S37S47. 
Mattos, R., C. R. Staples, and W. W. Thatcher. 2000. Effects of dietary fatty acid on reproduction in ruminants. Rev. Reprod. $5: 38-45$.

Moore, C. E., H. C. Hafliger III, O. B. Mendivil, S. R. Sanders, D. E. Bauman, and L. H. Baumgard. 2004. Increasing amounts of conjugated linoleic acid (CLA) progressively reduce milk fat synthesis immediately postpartum. J. Dairy Sci. 87:1886-1895.

NRC. 2001. Nutrient Requirements of Dairy Cattle. 7th ed. Natl. Acad. Press, Washington, DC.

Palmquist, D. L., A. D. Beaulieu, and D. M. Barbano. 1993. ADSA foundation symposium: Milk fat synthesis and modification. Feed and animal factors influencing milk fat composition. J. Dairy Sci. $76: 1753-1771$.

Peterson, D. G., J. A. Kelsey, and D. E. Bauman. 2002. Analysis of variation in cis-9, trans-11 conjugated linoleic acid (CLA) in milk fat of dairy cows. J. Dairy Sci. 85:2164-2172.

Petit, H. V., C. Germiquet, and D. Lebel. 2004. Effect of feeding whole, unprocessed sunflower seeds and flaxseed on milk production, milk composition, and prostaglandin secretion in dairy cows. J. Dairy Sci. 87:3889-3898.

Ponter, A. A., A.-E. Parsy, M. Saadé, J.-P. Mialot, C. Ficheux, C. Duvaux-Ponter, and B. Grimard. 2006. Effect of a supplement rich in linolenic acid added to the diet of post partum dairy cows on ovarian follicle growth, and milk and plasma fatty acid compositions. Reprod. Nutr. Dev. 46:19-29.
Prentice, R. L., B. Caan, R. T. Chlebowski, R. Patterson, L. H. Kuller, J. K. Ockene, K. L. Margolis, M. C. Limacher, J. E. Manson, L. M. Paker, E. Paskett, L. Phillips, J. Robbins, J. E. Rossouw, G. E. Sarto, J. M. Shikany, M. L. Stefanick, C. A. Thomson, L. Van Horn, M. Z. Vitolins, J. Wactawski-Wende, R. B. Wallace, S. Wassertheil-Smoller, E. Whitlock, K. Yano, L. Adams-Campbell, G. L. Anderson, A. R. Assaf, S. Beresford, H. R. Black, R. L. Brunner, R. G. Brzyski, L. Ford, M. Gass, J. Hays, D. Heber, G. Heiss, S. L. Hendrix, J. Hsia, F. A. Hubbell, R. D. Jackson, K. C. Johnson, J. M. Kotchen, A. Z. LaCroix, D. S. Lane, R. D. Langer, N. L. Lasser, and M. M. Henderson. 2006. Low-fat dietary pattern and risk of invasive breast cancer: The Women's Health Initiative randomized controlled dietary modification trial. JAMA 295:629-642.

Rukkwamsuk, T., M. J. H. Geelen, T. A. M. Druip, and T. Wensing. 2000. Interrelation of fatty acid composition in adipose tissue, serum, and liver of dairy cows during the development of fatty liver postpartum. J. Dairy Sci. 83:52-59.

Shingfield, K. J., C. K. Reynolds, G. Hervás, J. M. Griinari, A. S. Grandison, and D. E. Beever. 2006. Examination of the persistency of milk fatty acid composition responses to fish oil and sunflower oil in the diet of dairy cows. J. Dairy Sci. 89:714-732.

Staples, C. R., J. M. Burke, and W. W. Thatcher. 1998. Influence of supplemental fats on reproductive tissues and performance of lactating cows. J. Dairy Sci. 81:856-871. 